\title{
Game Edukasi Menghafal Doa-Doa Harian Sebagai Media Belajar Untuk Anak Usia Dini Berbasis Android
}

\author{
Topan Ramadhan SAN \\ Program Studi Informatika \\ Universitas Muhammadiyah Surakarta (UMS) \\ Surakarta, Indonesia \\ Topanr33@gmail.com
}

\author{
Fatah Yasin Al Irsyadi \\ Program Studi Informatika \\ Universitas Muhammadiyah Surakarta (UMS) \\ Surakarta, IndonesiaCity \\ Fatah.yasin@ums.ac.id
}

\begin{abstract}
Abstraksi-Doa merupakan inti ibadah dan yang paling berarti dari sesuatu itu (ibadah) karena bacaan doa dalam setiap ibadah kita itu mengandung doa. Pembelajaran doa sangat penting untuk dilakukan sejak usia dini. Proses pembelajaran di sekolah umumnya masih menggunakan media terbatas dalam penyampain materi yang cenderung monoton dan kurang menarik, untuk itu diperluhkan media pembelajaran yang menghibur dan menyenangkan salah satunya adalah dengan media permainan edukasi. Penelitian ini bertujuan untuk membuat sebuah game edukasi berbasis android untuk anak usia dini yang digunakan untuk membantu memudahkan siswa dalam belajar dan menghafal doa-doa harian. Penelitian dilakukan di PAUD Aisyiyah Pabelan diawali dengan melakukan proses pengamatan dan wawancara untuk melihat cara belajar siswa dalam memahami materi doa-doa harain yang diberikan guru pengajar. Game dibuat sesuai dengan kurikulum yang diajarkan dengan menggunakan software utama construct 2 yang disajikan dalam bentuk visual 2 dimensi. Pengujian aplikasi dilakukan dengan uji blackbox dan pengenalan game edukasi dengan mendemonstrasikan pada siswa, kemudian siswa mencoba memainkan game edukasi dengan didampingi oleh guru pengajar. Berdasarkan hasil pengujian blackbox dengan hasil aplikasi berjalan dengan baik, Sedangkan untuk hasil penilaian yang telah diberikan guru pengajar melalui kusioner menyatakan bahwa game yang dibuat memiliki tampilan yang menarik sehingga membuat minat belajar anak menjadi meningkat, game membuat anak lebih aktif karena secara tidak langsung mampu melatih kemampuan motorik halus pada anak, , serta game dapat digunakan oleh guru sebagai salah satu alternatif media bantu untuk memodifikasi suasana belajar menjadi lebih
\end{abstract}

\section{Katakunci- Anak, Construct 2, Doa Harian, Game Edukasi}

\section{Pendahuluan}

Doa merupakan suatu permohonan dan pujian dalam bentuk ucapan dari hamba yang rendah kedudukannya pada Rab Yang Mahatinggi. Doa itu adalah inti ibadah dan yang paling berarti dari sesuatu itu (ibadah), karena bacaan doa dalam setiap ibadah kita itu mengandung doa [2]. Kegiatan berdoa juga dianjurkan ketika seorang muslim akan memulai atau mengakhiri suatu aktivitas agar setiap aktivitas yang dilakukan selalu diliputi dengan perlindungan serta mendapatkan berkah dan keridhoan dari Nya. Doa juga memperjelas tanda bahwa manusia mengakui dia adalah makhluk yang lemah, tidak berdaya, tidak mempunyai kemampuan apapun dan selalu meminta pertolongan dari Allah SWT.

Pendidikan anak pada usia dini sangatlah penting untuk dilakukan. Khususnya pendidikan agama, dengan pemberian pendidikan agama islam diharapkan pembentukan karakter anak akan terbentuk sejak dini [1]. Materi pembelajaran agama islam yang disampaikan kepada anak biasanya berupa materi yang ringan, misalnya belajar doa-doa harian. Saat ini kebanyakan instansi pendidikan masih menggunakan metode pembelajaran yang bersifat konvensional, dimana proses pembelajaran ini anak terkadang merasa jenuh, bosan dan kurang menarik perhatian anak-anak terhadap materi pembelajaran yang disampaikan, karena pada umumnya anak usia dini sangat aktif bermain sehingga dalam proses pembelajaran lebih diutamakan menggunakan metode belajar sambil bermain. Metode ini akan lebih terkesan dalam memori otak anak-anak untuk pengetahuannya karena pada usia dini adalah masa-masa perkembangan memori otak sangat pesat [8].

Dalam melaksanakan proses belajar mengajar di PAUD Aisyiyah Pabelan Kartasura seorang guru hendaknya memiliki pemahaman yang baik tentang materi yang akan diberikan kepada anak. Pembelajaran yang diajarkan pada anak menggunakan metode belajar sambil bermain namun materi pembelajaran yang disampaikan umumnya masih menggunakan media terbatas seperti buku pembelajaran, papan tulis atau bahkan seorang guru memberikan penjelasan secara lisan pada anak-anak, penggunan cara tersebut cenderung kurang efektif dan effesien membuat anak merasa susah untuk memahami pelajaran juga pengetahuan yang diberikan. Selain itu proses pembelajaran tersebut hanya dilakukan di lingkungan sekolah saja, ketika anak-anak pulang sekolah mereka sibuk untuk bermain sehingga dapat menghambat proses pembelajaran. Permasalahan lainnya adalah belum adanya pemanfaatan media belajar yang interaktif dalam proses pembelajaran doa-doa harian. Hal 
tersebut akan mempengaruhi minat belajar anak semakin berkurang dan konsentrasi belajar pun akan menurun.

\section{DaSar TeOri dan Tinjauan Pustaka}

Perkembangan teknologi informasi saat ini sangat pesat terutama smartphone android. Perkembangan yang cepat juga berdampak pada berbagai aspek kehidupan termasuk pendidikan. Pemanfaatan media pembelajaran pada bidang pendidikan dapat memberikan solusi dan kemudahan dalam upaya untuk meningkatkan efektivitas proses belajar mengajar[5]. Salah satu contoh pemanfaatan media pembelajaran yang banyak disenangi oleh anak yaitu game. Game sendiri merupakan contoh multimedia yang dapat dipadukan dengan pembelajaran yang biasa disebut dengan game edukasi, game dengan tujuan edukasi ini dapat dijadikan sabagai salah satu media pembeajaran yang memiliki pola pembelajaran (learning by doing) pendidikan yang diberikan lewat praktek atau pembelajaran dengan praktek [3].

Penggunaan game sebagai sarana pendidikan bukan hal yang salah, karena game bersifat menghibur, menyenangkan dapat digunakan secara efektif di kelas sekolah, baik dalam kurikulum mata pelajaran dengan penekanannya pada informasi dan pengetahuan dan dalam lebih banyak program keterampilan dan kompetensi [7]. Game edukasi mempunyai keunggulan dalam beberapa aspek jika dibandingkan dengan metode pembelajaran konvensional. Salah satu keunggulan yang signifikan adalah adanya fasilitas animasi yang dapat meningkatkan daya ingat sehingga anak dapat menyimpan materi pelajaran dalam waktu yang lebih lama dibandingkan dengan pembelajaran konvensional [4]. Untuk itu perlu dikembangkan suatu aplikasi dalam bentuk media pembelajaran dan permainan edukatif untuk memfasilitasi kegiatan pembelajaran anak usia dini dengan tampilan menarik penuh dengan warna dan animasi yang dapat memikat anak sehingga anak dapat dengan mudah menerima dan mempelajari doa-doa harian yang diajarkan.

Pembuatan game edukasi ini menggunakan software Construct 2. Construct 2 adalah sebuah tool pembuat game berbasis HTML 5 yang dikhususkan untuk platform 2D. Dikembangkan oleh Scirra Ltd, Construct 2 tidak menggunakan bahasa pemrograman khusus karena semua perintah yang digunakan pada game diatur dalam EventSheet yang terdiri dari Event dan Action, memungkinkan siapa saja membuat game tanpa harus memiliki pengetahuan pemrograman [6]. Tujuan pembuatan aplikasi Game Edukasi Menghafal Doa-Doa Harian sebagai Media Belajar untuk Anak Usia Dini Berbasis Android ini dapat membantu memudahkan anak dalam memahami doa-doa harian melalui pembelajaran sambil bermain dengan cara menghafal dan mendengarkan sambil bermain serta lebih memanfaatkan waktu luang anak-anak yang tadinya terbuang karena diisi dengan hal-hal yang tidak bermanfaat dengan melalui aplikasi game edukasi ini efisiensi waktu anak-anak menjadi lebih bermanfaat.

\section{METODE}

Penelitian ini dimulai dengan melakukan pengamatan serta pencatatan data untuk mengetahui secara langsung permasalahan apa saja yang ada dalam proses kegiatan belajar mengajar dan mengidentifikasi solusi penyelesaian untuk mengatasi masalah tersebut. Penulis juga melakukan wawancara terhadap guru pengajar di PAUD Aisyiyah Pabelan untuk mendapatkan data. Hasil wawancaranya adalah sebagai berikut:

a. Anak memerluhkan pendamping dan pembimbing dalam proses belajar.

b. Anak mudah merasa bosan dan jenuh dalam menerima materi yang disampikan guru, sehingga guru perlu memodifikasi suasana belajar agar dapat meningkatkan ketertarikan anak misalnya melalui penggunaan game edukasi dan media pembelajaran yang interaktif.

c. Anak lebih berminat dan bersemangat dalam menyerap materi pembelajaran dengan pola belajar sambil bermain.

d. Kurikulum pembelajaran yang digunakan di PAUD Aisyiyah Pabelan disesuaikan dengan Diknas

\section{A. Peracangan Sistem}

Gambaran umum dari game edukasi yang dibuat adalah sebagai berikut :

a. Game edukasi ini berisi materi tentang pengenalan doadoa harian untuk anak usia dini sesuai dengan kurikulum pada modul pembelajaran yang digunakan di PAUD Aisyiyah Pabelan.

b. Software untuk membuat game ini menggunakan Construct 2 dengan tampilan 2D.

c. Game ini terdiri dari 8 scene, yaitu scene 0 sampai 7 .

d. Pada menu tampilan awal game, terdapat 3 tombol utama yaitu menu belajar, menu bermain, dan tombol suara.

e. Pada tampilan menu belajar terdapat pilihan doa-doa, apabila memilih salah satu doa makan akan menuju ke tampilan menu doa tersebut.

f. Pada tampilan menu bermain berisi menu permainan tebak doa, pasang doa dan cocokan doa, dimana di setiap awal permainan terdapat petunjuk bagaimana cara memainkan game tersebut berupa teks dan suara.

g. Pada setiap permainan menampilkan score disertai suara yang menunjukkan bahwa jawaban itu benar atau salah, apabila jawaban yang dipilih pengguna itu benar maka score akan bertambah namun jika pengguna menjawab salah maka score akan berkurang.

h. Pada akhir permainan akan muncul tampilan selesai berupa total score.

Storyboard adalah serangkaian sketsa secara visual untuk menggambarkan urutan atau alur dari sistem yang akan dibangun. Storyboard game edukasi doa harian ditunjukan pada Gambar 1 sampai Gambar 8 berikut. 


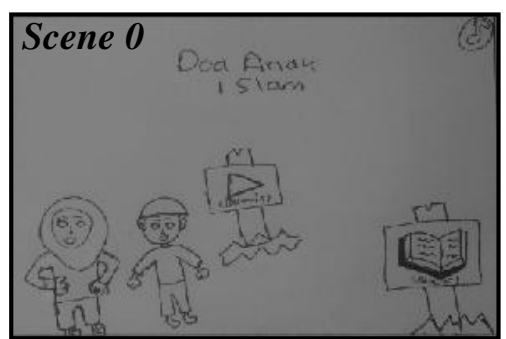

Gambar 1. Storyboard menu utama.

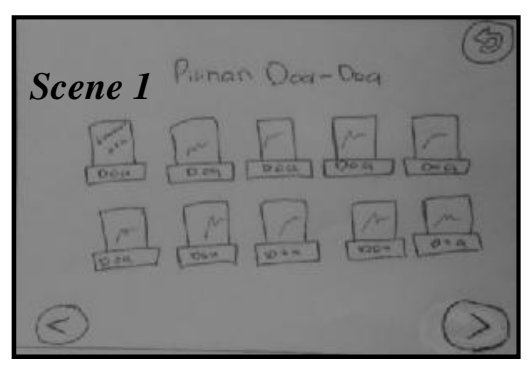

Gambar 2. Storyboard menu belajar.

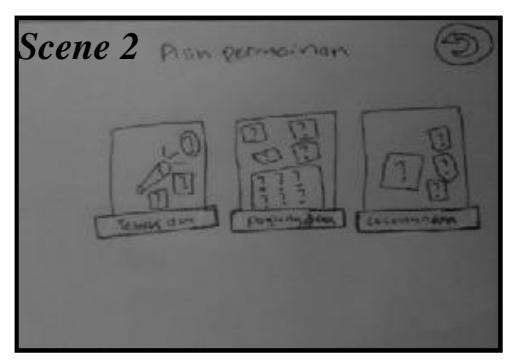

Gambar 3. Storyboard menu bermain.

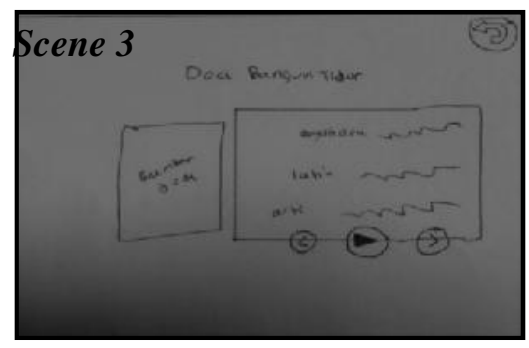

Gambar 4. Storyboard menu doa

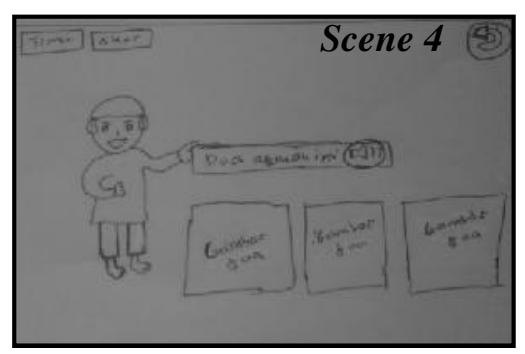

Gambar 5. Storyboard permainan tebak doa.

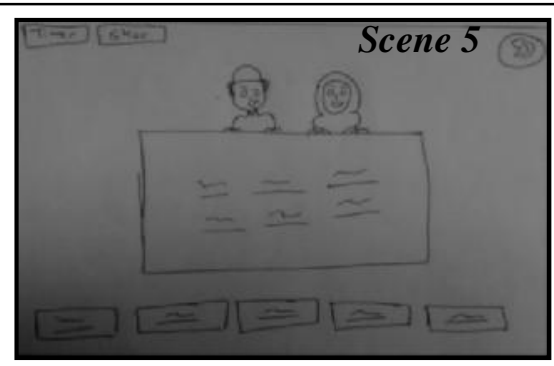

Gambar 6. Storyboard permainan pasang doa.

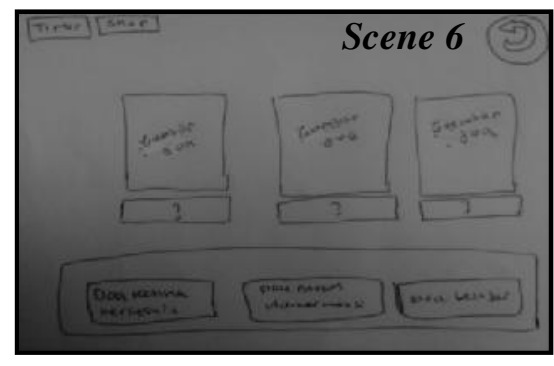

Gambar 7. Storyboard permainan cocokan doa.

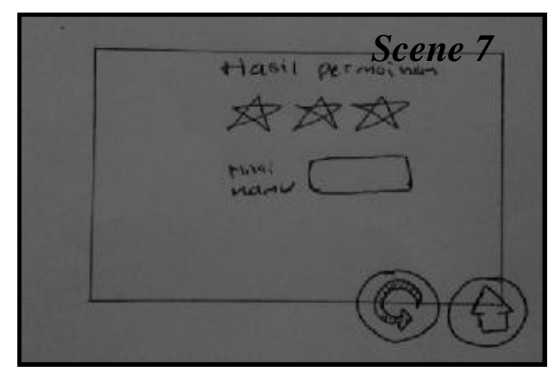

Gambar 8. Storyboard permainan cocokan doa.

Permainan ini terdiri dari 8 scene yaitu scene 0 sampai 7, scene 0 merupakan tampilan awal game saat aplikasi dibuka berisi 3 tombol utama diantaranya menu belajar, menu bermain, dan tombol suara seperti pada gambar 1. Scene 1 adalah halaman menu belajar berisi materi pilihan doa-doa seperti pada gambar 2. Scene 2 adalah halaman menu bermain terdapat permainan berupa tebak doa, pasang doa dan cocokkan doa seperti pada gambar 3. Selanjutnya pada gambar 4 yaitu scene 3 berisi tampilan menu doa yang menampilkan ayat, terjemahan doa, gambar animasi, dan suara lafal doa. Kemudian pada gambar 5 yaitu scene 4 adalah tampilan permainan untuk menebak gambar ilustrasi doa sesuai dengan suara yang keluar. Scene 5 adalah tampilan permainan untuk menyusun potongan ayat doa seperti pada gambar 6. Scene 6 adalah tampilan permainan untuk mencocokkan nama doa sesuai dengan gambar ilustrasi yang muncul seperti pada gambar 7. Terdapat juga halaman hasil akhir permainan yaitu scene 7 seperti pada gambar 8 .

\section{B. Pembuatan Sistem}

Pembuatan aplikasi game ini menggunakan software utama yaitu Construct 2 serta software pendukung lainnya 
seperti CorelDraw X7, Online Audio Converter dan phoneGap untuk build ke android.

\section{Pengujian Sistem}

Pada tahap ini pengujian dilakukan setelah aplikasi selesai dibuat dengan menggunakan uji BlackBox dan uji penerimaan pengguna melalui kuisioner. Uji BlackBox dilakukan oleh penulis terhadap beberapa unit sistem antarmuka grafis, suara, dan kontrol game apakah sudah berjalan sesuai yang diharapkan atau belum. Sedangkan untuk kuisioner, pengujian dilakukan dengan melibatkan siswa-siswi dan didampingi oleh guru pengajar di PAUD Aisyiyah Pabelan, Setelah itu nantinya guru diminta untuk mengisi kuesioner dan data kuesioner digunakan untuk menganalisa aplikasi yang telah diujicobakan.

\section{HASIL DAN PEMBAHASAN}

Penelitian ini menghasilkan sebuah game edukasi berbasis android tentang doa-doa harian untuk anak usia dini. Software untuk membuat game ini menggunakan Construct 2, CorelDraw X7 untuk membuat aset berupa objek gambar, menyiapkan audio suara lalu membuat file suara dari format .mp3 ke .wav/.ogg menggunakan Online Audio Converter. Berikut pembahasan hasil penelitian game edukasi mengahafal doa-doa harian sebagai media belajar untuk anak usia dini berbasis android.

\section{A. Hasil Aplikasi}

1. Halaman Menu Utama

Tampilan halaman menu utama seperti pada Gambar 9 merupakan awal dari permainan saat pertama kali membuka aplikasi. Pada menu utama menampilkan 3 tombol yaitu menu belajar berupa daftar pilihan doa, menu bermain berupa daftar pilihan permainan yang dapat dipilih untuk bermain, sedangkan tombol suara untuk mengatur backsound dan tombol pada game edukasi.

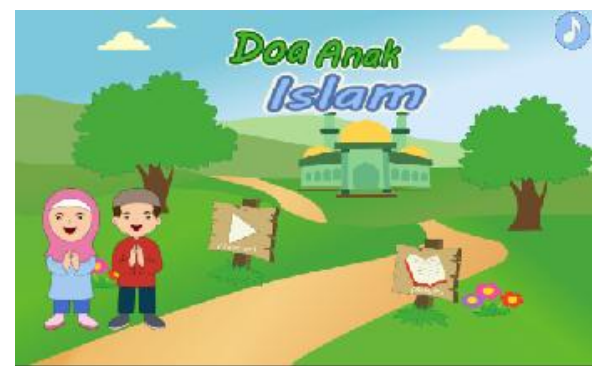

Gambar 9. Halaman menu utama.

\section{Halaman Menu Belajar dan Menu Doa}

Tampilan halaman menu belajar pada Gambar 10 ini berisikan daftar 30 pilihan doa harian berupa gambar ilustrasi dan nama doa terdapat juga tombol ke daftar pilihan doa selanjutnya, dan tombol ke daftar pilihan doa sebelumnya. Apabila pengguna memilih salah satu doa maka akan menuju ke halaman menu doa tersebut seperti pada Gambar 11. Menu doa ini berisi detail doa yaitu berupa ayat, terjemahan doa dan gambar animasi doa, jika menekan gambar animasi doa maka gambar animasi akan bergerak serta di menu dilengkapi juga dengan tombol play untuk mendengarkan lafal doa.

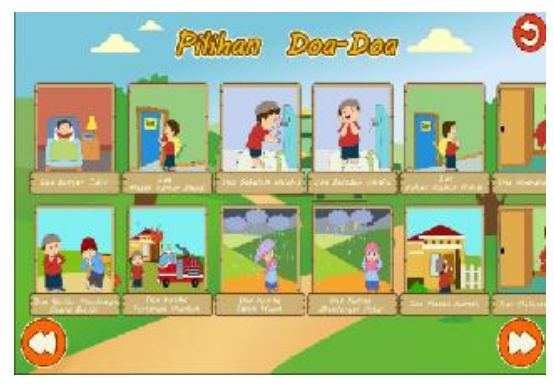

Gambar 10. Halaman menu belajar.

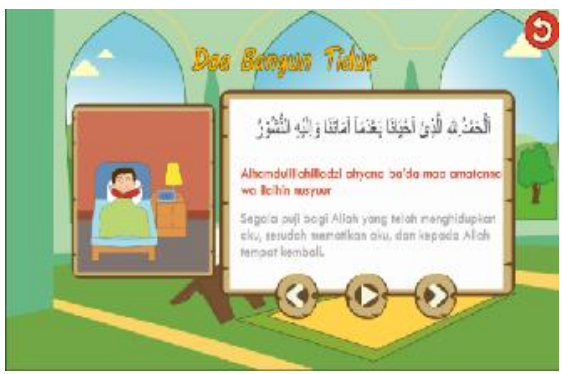

Gambar 11. Halaman menu doa.

3. Halaman Menu Bermain

Tampilan halaman menu bermain terdapat 3 pilihan permainan yaitu tebak doa, pasang doa dan cocokan doa seperti pada gambar 12, dalam permainan setiap pertanyaan mengacu pada materi di menu belajar.

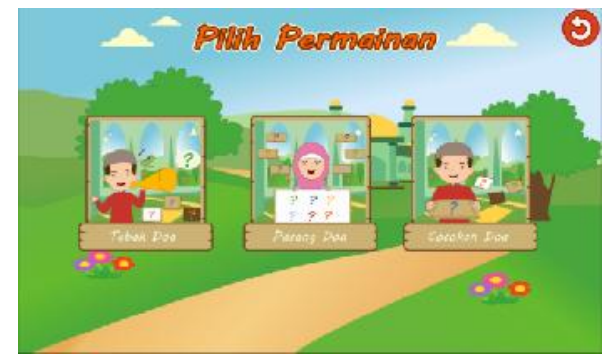

Gambar 12. Halaman menu bermain

4. Halaman Permainan Tebak Doa

Pada Gambar 13 menunjukkan tampilan permainan tebak doa, dimana pada awal permainan terdapat petunjuk agar pengguna bisa memahami cara bermain di permainan tersebut. Pada permainan ini pengguna harus memilih salah satu jawaban gambar ilustrasi doa dengan benar yang sudah tersedia sesuai suara lafal doa yang keluar, setiap pertanyaan dalam permainan disajikan dalam bentuk audio suara.

\section{Halaman Permainan Tebak Doa}

Gambar 14 menunjukkan tampilan permainan pasang doa terdapat petunjuk yang menjelaskan cara bermain dan tombol 
kembali ke halaman menu bermain. Pada permainan ini setiap pertanyaan akan mengeluarkan suara lafal doa secara berulang-ulang, pengguna harus memilih potongan ayat doa yang sudah diacak pada kotak pilihan jawaban, lalu mendragnya ke bagian kotak jawaban sesuai dengan potongan ayat doa yang cocok kemudian di drop untuk menyusun potongan ayat doa tersebut menjadi lafal doa yang utuh.
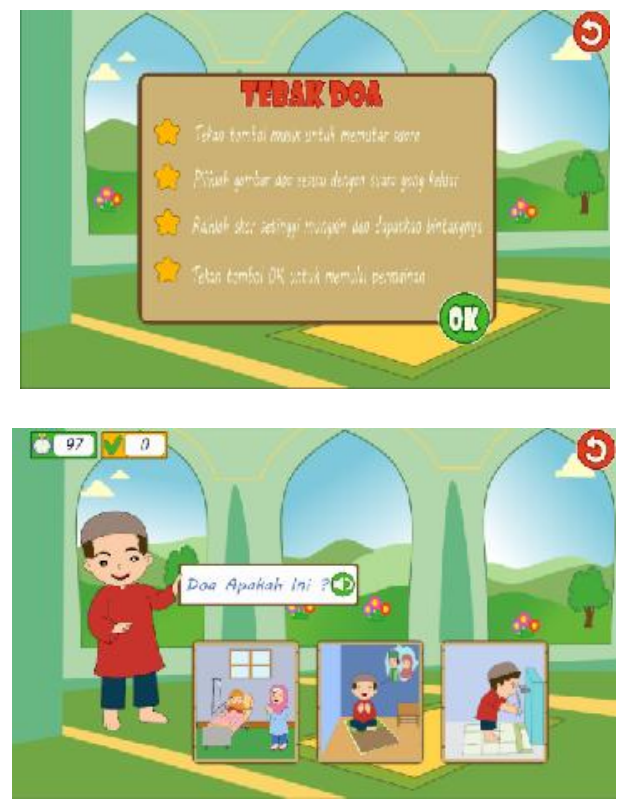

Gambar 13. Tampilan petunjuk permainan tebak doa
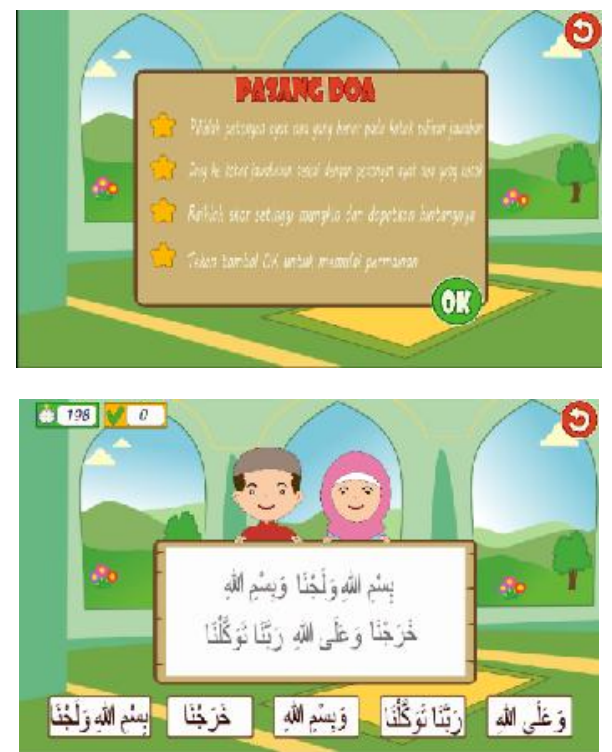

Gambar 14. Tampilan petunjuk permainan pasang doa

6. Halaman Permainan Cocokan Doa

Gambar 15 menunjukkan tampilan permainan cocokkan doa yang memiliki konsep kurang lebih sama dengan permainan sebelumnya yaitu "Pasang Doa". Sebelum memulai permainan akan tampil halaman petunjuk. Pada permainan ini pengguna harus memilih nama doa yang cocok dan memindahkannya dengan cara di drag lalu di drop pada kotak jawaban sesuai dengan gambar ilustrasi doa yang muncul, gambar ilustrasi pada pertanyaan dapat ditekan dan akan mengeluarkan suara lafal doa.
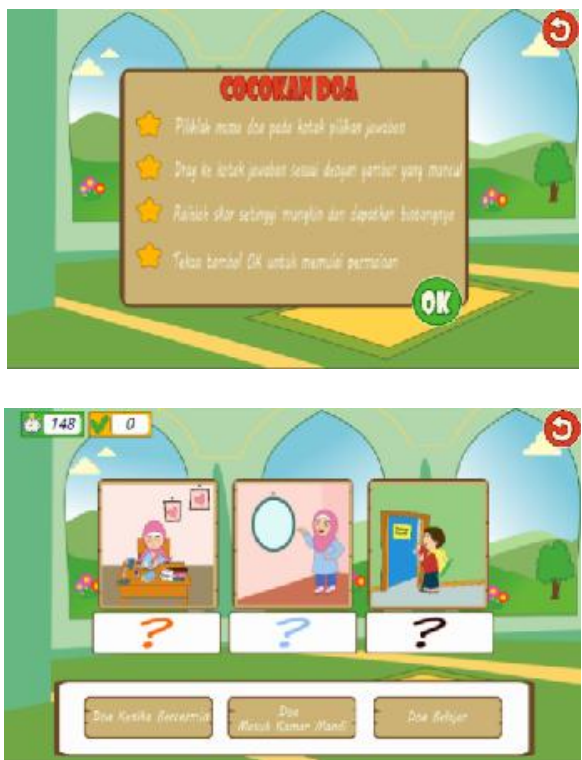

Gambar 15. Tampilan petunjuk permainan cocokan doa.

\section{Halaman Hasil Akhir Permainan}

Tampilan hasil akhir permainan merupakan halaman yang menujukkan bahwa permainan telah selesai dimainkan, dimana halaman ini akan tampil apabila semua pertanyaan pada permainan sudah terjawab semua atau jika waktu bermain sudah habis. Pada halaman ini berisi total score yang telah ditentuhkan yang diperoleh saat memainkan permainan dan gambar animasi bintang yang akan muncul apabila pengguna behasil mendapatkan score yang telah ditentuhkan pada permainan serta tersedia tombol pilihan yaitu tombol main lagi untuk kembali ke menu bermain dan tombol home untuk kembali ke halaman menu utama seperti pada gambar 1

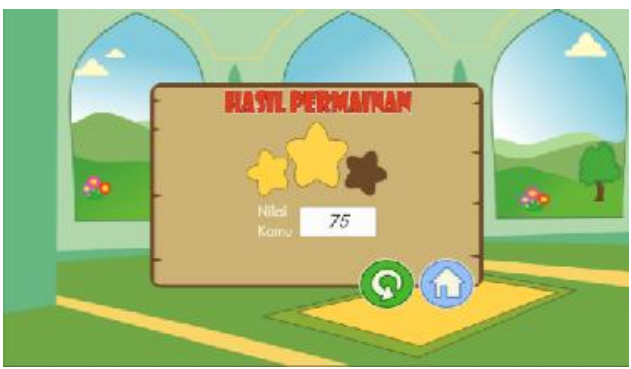

Gambar 16. Hasil akhir permainan 


\section{B. Hasil Pengujian}

Pengujian penelitian ini dilakukan menggunakan 2 cara yaitu uji BlackBox dan uji penerimaan pengguna. Berikut adalah hasil pengujian dari aplikasi game edukasi.

\section{Uji Blackbox}

Pada tahapan uji BlackBox aplikasi game edukasi ini dilakukan secara langsung oleh penguji menggunakan laptop Asus dengan windows 10 dan beberapa perangkat mobile dengan sistem operasi android untuk memastikan bahwa suatu masukan akan menjalankan proses yang tepat dan menghasilkan output sesuai dengan rancangan. Selanjutnya hasil pengujian aplikasi game edukasi doa-doa harian dapat dilihat pada tabel 1. Dari tabel 1 dapat disimpulkan bahwa fungsi utama pada game edukasi sudah berjalan baik sesuai dengan konsep dan alur cerita permainan dan menunjukkan hasil uji "Sesuai" pada tiap fungsi dan tombol dari permainan.

\section{Uji Penerimaan Pengguna}

Proses pengujian ini diawali dengan pengenalan aplikasi game edukasi dengan cara mendemonstrasikan pada siswa kelompok B di PAUD Aisyiyah Pabelan yang di bimbing oleh beberapa guru pengajar. Guru mengamati dan memberikan bimbingan, kemudian siswa mencoba memainkan game edukasi sesuai panduan peneliti. Setelah mendemokan aplikasi game ini peneliti memberikan kuisioner kepada guru pengajar sebagai bentuk penilaian terhadap aplikasi game edukasi. Jumlah responden yang memberikan tanggapan terhadap aplikasi yang telah didemokan sebanyak 15 orang. Berikut adalah hasil analisis dari kuisioner tersebut.

a. Tanggapan responden untuk pertanyaan nomor 1, yaitu “ Tampilan game menarik ", menyatakan bahwa terdapat 8 responden yang menjawab sangat setuju (SS), sedangkan 7 responden lainnya menjawab setuju (S). Artinya game ini memiliki tampilan yang menarik.

b. Tanggapan responden untuk pertanyaan nomor 2, yaitu “ Game bersifat interaktif ", menyatakan bahwa terdapat 6 responden yang menjawab sangat setuju (SS), sedangkan 9 responden lainnya menjawab setuju (S). Artinya game ini mengajak anak untuk menggunakan indera sentuhan sebagai aksi dalam permainan dengan tetap melibatkan indera pendengaran dan pengelihatan sehingga game ini cukup interaktif.

c. Tanggapan responden untuk pertanyaan nomor 3, yaitu “ Game mudah dimainkan ", menyatakan bahwa terdapat 6 responden yang menjawab sangat setuju (SS), sedangkan 9 responden lainnya menjawab setuju (S). Artinya game edukasi ini tidak terlalu rumit dari segi fitur yang ada sehingga pengguna mudah memainkannya.

d. Tanggapan responden untuk pertanyaan nomor 4, yaitu “ Kesesuaian ilustrasi gambar ", menyatakan bahwa terdapat 8 responden yang menjawab sangat setuju (SS), sedangkan 7 responden lainnya menjawab setuju (S). Artinya gambar ilustrasi yang ada sesuai dengan tema/judul doa.
TABEL I. UJI BLACKBOX APLIKASI GAME EDUKASI

\begin{tabular}{|c|c|c|c|c|}
\hline Yang diuji & Pengujian & Input & Output & Hasil \\
\hline \multirow{3}{*}{$\begin{array}{l}\text { Menu } \\
\text { Utama }\end{array}$} & Belajar & $\begin{array}{l}\text { Klik icon } \\
\text { menu } \\
\text { belajar }\end{array}$ & $\begin{array}{l}\text { Menampilkan daftar } \\
\text { pilihan doa-dao harian }\end{array}$ & Sesuai \\
\hline & Bermain & $\begin{array}{l}\text { Klik icon } \\
\text { menu } \\
\text { bermain }\end{array}$ & $\begin{array}{l}\text { Menampilkan daftar } \\
\text { pilihan permainan }\end{array}$ & Sesuai \\
\hline & $\begin{array}{l}\text { Tombol } \\
\text { Suara }\end{array}$ & $\begin{array}{l}\text { Klik } \\
\text { pengatura } \\
\text { n suara } \\
\text { on/off }\end{array}$ & Dapat berfungsi & Sesuai \\
\hline $\begin{array}{l}\text { Menu } \\
\text { Belajar }\end{array}$ & $\begin{array}{c}\text { Daftar } \\
\text { pilihan doa }\end{array}$ & $\begin{array}{l}\text { Klik } \\
\text { gambar } \\
\text { ilustrasi } \\
\text { doa }\end{array}$ & $\begin{array}{c}\text { Menampilkan detail doa } \\
\text { sesuai yang dipilih beserta } \\
\text { tombol play dan gambar } \\
\text { animasi }\end{array}$ & Sesuai \\
\hline \multirow{2}{*}{ Menu Doa } & $\begin{array}{c}\text { Gambar } \\
\text { animasi doa }\end{array}$ & $\begin{array}{l}\text { Klik pada } \\
\text { gambar } \\
\text { animasi } \\
\text { doa }\end{array}$ & $\begin{array}{c}\text { Gambar animasi doa akan } \\
\text { bergerak }\end{array}$ & Sesuai \\
\hline & $\begin{array}{l}\text { Tombol play } \\
\text { dan stop }\end{array}$ & $\begin{array}{l}\text { Klik } \\
\text { masing- } \\
\text { masing } \\
\text { tombol }\end{array}$ & $\begin{array}{l}\text { Mengeluarkan dan } \\
\text { menstop suara lafal doa }\end{array}$ & Sesuai \\
\hline \multirow[b]{3}{*}{$\begin{array}{l}\text { Menu } \\
\text { Bermain }\end{array}$} & $\begin{array}{l}3 \text { daftar } \\
\text { pilihan } \\
\text { permainan }\end{array}$ & $\begin{array}{c}\text { klik } \\
\text { masing- } \\
\text { masing } \\
\text { icon } \\
\text { permainan }\end{array}$ & $\begin{array}{l}\text { Menuju ke halaman } \\
\text { permainan yang dipilih }\end{array}$ & Sesuai \\
\hline & Scoring & $\begin{array}{l}\text { Lakukan } \\
\text { debug } \\
\text { permainan }\end{array}$ & $\begin{array}{l}\text { Score dapat bertambah } \\
\text { dan berkurang dalam } \\
\text { setiap permainan }\end{array}$ & Sesuai \\
\hline & Timer & $\begin{array}{l}\text { Lakukan } \\
\text { sistem } \\
\text { timering }\end{array}$ & $\begin{array}{l}\text { Menampilkan waktu } \\
\text { permainan }\end{array}$ & Sesuai \\
\hline \multirow[b]{2}{*}{$\begin{array}{l}\text { Permainan } \\
\text { Tebak } \\
\text { Doa }\end{array}$} & $\begin{array}{l}\text { Tombol } \\
\text { Musik }\end{array}$ & $\begin{array}{l}\text { Klik icon } \\
\text { musk }\end{array}$ & $\begin{array}{c}\text { Mengeluarkan suara lafal } \\
\text { doa }\end{array}$ & Sesuai \\
\hline & $\begin{array}{l}\text { Pemilihan } \\
\text { jawaban } \\
\text { sesuai } \\
\text { pertanyaan }\end{array}$ & $\begin{array}{l}\text { Klik pada } \\
\text { jawaban } \\
\text { pilihan } \\
\text { ganda }\end{array}$ & $\begin{array}{c}\text { Apabila salah score akan } \\
\text { berkurang dan apabila } \\
\text { benar score akan } \\
\text { bertambah }\end{array}$ & Sesuai \\
\hline $\begin{array}{c}\text { Permainan } \\
\text { Pasang Doa }\end{array}$ & $\begin{array}{l}\text { Pemilihan } \\
\text { potongan } \\
\text { ayat doa }\end{array}$ & $\begin{array}{l}\text { Drag and } \\
\text { drop } \\
\text { potongan } \\
\text { ayat doa }\end{array}$ & $\begin{array}{c}\text { Potongan ayat doa akan } \\
\text { terpasang ke kotak } \\
\text { jawaban yang benar }\end{array}$ & Sesuai \\
\hline $\begin{array}{l}\text { Permainan } \\
\text { Cocokan } \\
\text { Doa }\end{array}$ & $\begin{array}{l}\text { Pemilihan } \\
\text { nama doa }\end{array}$ & $\begin{array}{l}\text { Drag and } \\
\text { drop } \\
\text { potongan } \\
\text { nama doa }\end{array}$ & $\begin{array}{c}\text { Nama doa akan } \\
\text { menempel ke kotak } \\
\text { jawaban yang benar }\end{array}$ & Sesuai \\
\hline \multirow{2}{*}{$\begin{array}{l}\text { Halaman } \\
\text { Hasil Akhir } \\
\text { Permainan }\end{array}$} & $\begin{array}{l}\text { Tombol } \\
\text { main lagi }\end{array}$ & $\begin{array}{l}\text { Klik icon } \\
\text { ulang }\end{array}$ & $\begin{array}{l}\text { Menuju ke halaman } \\
\text { menu bermain }\end{array}$ & Sesuai \\
\hline & $\begin{array}{l}\text { Tombol } \\
\text { home }\end{array}$ & $\begin{array}{l}\text { Klik pada } \\
\text { icon } \\
\text { rumah }\end{array}$ & $\begin{array}{l}\text { Menuju ke halaman } \\
\text { menu utama }\end{array}$ & Sesuai \\
\hline $\begin{array}{l}\text { Semua } \\
\text { Permaina } \\
n\end{array}$ & $\begin{array}{l}\text { Semua } \\
\text { tombol di } \\
\text { permaina } \\
\mathrm{n}\end{array}$ & $\begin{array}{l}\text { Klik } \\
\text { masing- } \\
\text { masing } \\
\text { tombol }\end{array}$ & $\begin{array}{l}\text { Setiap tombol dalam } \\
\text { permainan berfungsi } \\
\text { dengan benar }\end{array}$ & Sesuai \\
\hline
\end{tabular}

e. Tanggapan responden untuk pertanyaan nomor 5, yaitu “ Anak-anak antusias dengan game ini ", menyatakan bahwa terdapat 8 responden yang menjawab sangat setuju (SS), 
sedangkan 7 responden lainnya menjawab setuju (S). Artinya anak-anak sangat tertarik dalam bermain game ini.

f. Tanggapan responden untuk pertanyaan nomor 6, yaitu “ Materi sesuai dengan kurikulum yang diajarakan ", menyatakan bahwa terdapat 6 responden yang menjawab sangat setuju (SS), sedangkan 9 responden lainnya menjawab setuju (S). Artinya aplikasi game yang telah dibuat berisi materi-materi yang sudah sesuai dengan kurikulum di PAUD Aisyiyah Pabelan.

g. Tanggapan responden untuk pertanyaan nomor 7, yaitu “ Game dapat membantu anak mengenal doa harian ", menyatakan bahwa terdapat 9 responden yang menjawab sangat setuju (SS), sedangkan 6 responden lainnya menjawab setuju (S). Artinya materi-materi yang ada dapat diajdikan media pembelajaran untuk anak dalam mengenal doa-doa harian.

h. Tanggapan responden untuk pertanyaan nomor 8, yaitu “ game dapat membantu guru dalam memvariasikan metode pembelajaran ", menyatakan bahwa terdapat 12 responden yang menjawab sangat setuju (SS), sedangkan 3 responden lainnya menjawab setuju (S). Artinya game edukasi dapat menjadi alternatif bagi guru untuk membantu menyampaikan materi kepada anak-anak.

i. Tanggapan responden untuk pertanyaan nomor 9, yaitu “ game dapat dijadikan sarana belajar dan bermain ", menyatakan bahwa terdapat 9 responden yang menjawab sangat setuju (SS), sedangkan 6 responden lainnya menjawab setuju (S). Artinya game edukasi secara keseluruhan dapat berfungsi sebagai alat belajar.

j. Tanggapan responden untuk pertanyaan nomor 10, yaitu “ Penggunaan android sebagai media cukup mudah “, menyatakan bahwa terdapat 5 responden yang menjawab sangat setuju (SS), sedangkan 10 responden lainnya menjawab setuju (S). Artinya penggunaan android sebagai alat pendukung dalam proses pembelajaran dapat dipergunakan dengan mudah.

\section{PENUTUP}

Berdasarkan hasil dari penelitian dapat disimpulkan bahwa :

1. Game edukasi memiliki tampilan yang menarik dapat membuat minat belajar anak terhadap materi pembelajaran menjadi meningkat serta game ini cukup interkatif membuat anak antusias untuk memainkan game dan lebih aktif karena secara tidak langsung mampu melatih kemampuan motorik halus yang diperoleh ketika anak menyentuh dan memegang dengan menggunakan jarinya sebagai aksi dalam permainan.

2. Game edukasi doa-doa harian ini sesuai dengan kurikulum yang diajarakan di PAUD Aisyiyah Pabelan berisi menu materi doa-doa harian kemudian menu permainan menebak gambar doa sesuai lafal doa yang keluar, permainan menyusun potongan ayat doa menjadi ayat doa yang utuh serta permainan mencocokan nama doa sesuai gambar ilustrasi doa yang muncul dan game ini dapat membantu memudahkan anak dalam belajar menghafal doa-doa harian sambil bermain, sehingga muncul perasaan senang, gembira, dan tidak membosankan.

Penggunaan game edukasi melalui media android dirasa cukup mudah untuk digunakan sebagai salah satu alternatif media bantu bagi guru yang dapat digunakan untuk memodifikasi suasana belajar menjadi lebih menyenangkan, sehingga dengan perasaan senang diharapkan anak bisa lebih mudah memahami materi pembelajaran yang disampaikan.

\section{DAFTAR PUSTAKA}

[1] Suparni. (2016). Metode Pembelajaran Membaca Doa Berbasis Multimedia untuk Anak Usia Dini. Indonesian Journal on software Engineering, 1(2), $57-63$.

[2] Hamadi, M. R., Lumenta, A., \& Putro, M. D. (2017). Rancang Bangun Aplikasi Game Edukasi Hafalan Doa Agama Islam. Jurnal Teknik Informatika, 1(12), ISSN: 2301-8364.

[3] Vitianingsih, A. V. (2016). Game Edukasi Sebagai Media Pembelajaran Pendidikan Anak Usia Dini. Jurnal Inform, 1(1), 39-46.

[4] Wijayanto, P., \& Siradj, Y. (2017). The Educational Game "Indonesian Tribes" for the Kindergarten Students. International Journal of Pedagogy and Teacher Education (IJPTE), 1(1), 27-36

[5] Hermansyah, Nurhayati, \& Gustomi, L. F. (2017). Desain Aplikasi Pembelajaran Doa-doa Harian Berbasis Game Edukasi. Jurnal sisfotek, 5(2), 81-85.

[6] Riska, D., Jayanti, W. E., \& Meilinda, E. (2017). Pembuatan Media Pembelajaran Interaktif "Anak Muslim" Berbasis Android Menggunkan Construct 2. Jurnal Khatulistiwa Informatika, 2(5), 52-158.

[7] Kokalia, G., Drigas, A., Economou, A., Roussos, P., \& Choli, S. (2017). The Use of Serious Games in Preschool Education. International Journal of Emerging Technologies in Learning (iJET), 1(12), 15-27.

[8] Jones, S. (2016). Pembelajaran Berbasis Multimedia Pengenalan Binatang dan Alat Transportasi untuk Anak Usia Dini 2-3 Tahun. Jurnal Teknologi, 1(9), 78-8. 